\title{
Jeg tror for at elske
}

\section{Den negative teologi hos Johannes af korset ${ }^{1}$}

\section{Cand.theol. Thomas Emil Horneman-Thielcke}

Abstract: The purpose of this article, "I believe in order to love: Negative theology in the writings of St. John of the Cross", is threefold. First we see how St. John uses classical negative theology as the basis of his spiritual programme. This is of especial interest because John manages to transform the theoretical method of apophatic discourse into a practical spiritual process. In this spiritual programme, discourse about God results in the soul's refusal of the entire creation in an attempt to move closer to God through faith. This is particularly obvious in his metaphorical expression "the dark night", which can be best interpreted in the light of Christ's passion, death and resurrection. The second purpose of this article is exactly to show how St. John uses the agony and pain of Christ as a model for the soul's suffering in "the dark night". Thirdly the aim is to put St. John's negative theology in a contemporary and postmodern theological discourse and, in the light of this study, see if a new theological reading and understanding of it is possible.

Key words: Negative theology - St. John of the Cross - "the dark night" - asceticism - faith - contemplation - kenosis - plerosis - Rowan Williams - Graham Ward - Jacques Derrida.

Den negative teologi eller via negativa (græsk: 'apophasis', egl. væk fra tale, sammenbrud af tale) bygger som teoretisk metode på overbevisningen om, at det kun er muligt at sige noget om, hvad Gud ikke er. ${ }^{2}$

1. Artiklen er en bearbejdet version af mit speciale: Juan de la Cruz og den negative teologi, Københavns Universitet 2009. De danske oversættelser af Johannes af Korset er forfatterens egne og baserer sig på den spanske grundtekst fra San Juan de la Cruz, Obras Completas 5. edición critica (Madrid: Editorial de Espiritualidad 1993).

2. Denys Turner viser, at den etymologiske betydning af sammensætningen af de græske ord teologi og apofase leder til sprogets forfejlede tale om Gud: “...If we attend the Greek etymology of the word theology, then the curious state of the linguistic affairs results from its combination with the word apophatic. For theology means 'discourse about God' or 'divine discourse', so the expression 'apophatic theology' ought to mean something like: 'that speech about God which is failure of speech." Denys Turner, The Darkness of God - Negativity in Christian Mysticism (Cambridge: Cambridge University Press 1995), 20. 
Metoden benyttes til gradvist at benægte og diskvalificere udsagn om Gud. Sproget er ifølge den negative teologi ikke i stand til at tale fyldestgørende om Gud uden at begrænse ham. Den infinitte Gud kan med andre ord ikke rummes i det finitte sprog. Den negative teologi beskæftiger sig derfor med sprogets grænser for at beskrive den transcendente Gud. ${ }^{3}$ Det er vigtigt ikke at betragte denne metode som adskilt fra den såkaldte affirmative eller katafatiske metode. Forholdet mellem disse to skal i langt højere grad betragtes som et vekselvirkende og synergetisk sammenspil, i hvilket den affirmative metode er en forudsætning for den apofatiske. ${ }^{4}$ Den affirmative metode etablerer en mulighed for sprogligt at tale om Gud, hvorefter den apofatiske metode fastholder de åbenlyse begrænsninger, sproget indeholder i dets forsøg på at beskrive Gud. ${ }^{5}$ Gud kan derfor ved disse to metoder betegnes som værende både præsent, kendt og immanent, og skjult, ukendt og transcendent.

Den negative teologi bygger desuden også på, at den menneskelige forstand ikke er adækvat i forhold til Guds ratio og derfor ikke kan begribe, forestille sig eller forstå ham. ${ }^{6}$ Det betyder, at forstandens ytringer om Gud altid er utilstrækkelige og sekundære i forhold til, hvad Gud i virkeligheden er. Selvom dette er tilfældet, så forbliver den negative teologi imidlertid ikke tavs om Gud. Tværtimod forsøger den at omgå de latente problemer, der eksisterer i både sproget og forstanden ved at beskrive Gud i paradoksale vendinger og metaforer. At det forholder sig sådan, kommer særligt tydeligt til udtryk i Den mystiske teologi, et værk af én af den negative teologis største eksponenter, Dionysios Areopagiten (ca. 5. årh.). ${ }^{7}$ I værket beskrives, hvorledes sjælen i et 'erkendelsesløst mørke' bliver forenet med en Gud, der bedst lader sig beskrive som et 'strålende mørke'. Dionysios er ikke den første forfatter, der fremhæver, at sjælen møder Gud i et 'mør-

3. Oliver Davies \& Denys Turner, "Introduction", Silence and the Word, red. Oliver Davies \& Denys Turner (Cambridge: Cambridge University Press 2008), 3.

4. Mark A. McIntosh understreger den sammenhæng, der eksisterer imellem den katafatiske og apofatiske metode: "It begins by tracing the sounding forth (the cataphasis) of God's glory in divine selfexpression - from the eternal trinitarian life to the creation of the universe. Then it moves towards consummation by a series of 'ascending' dialectical negations (the apophasis) into the eternally fruitful darkness of unknowing, which is the only real knowing a creature can have of God." Mark A. McIntosh, Mystical Theology, The Integrity of Spirituality and Theology (Oxford: Blackwell Publishers Ltd. 1998), 122.

5. Deirdre Carabine, The Unknown God (Louvain: Peeters Press 1995), 2.

6. S. Thomae Aquinatis, Opera Omnia vol. 3 - Questiones Disputatae - De Potentia (Stuttgart: Friedrich Frommann Verlag 1980), 244. De Potentia 7.5 resp. ad obi. xiv.

7. Dionysios Areopagiten, Den mystiske teologi og de guddommelige navne (København: Sankt Ansgar Forlag 1998, oversat fra græsk ved Jørgen Pedersen), 56-58. 
ke'. Metaforen 'mørke' bliver allerede brugt af både Filon af Alexandria (10 f.Kr - 40 e.Kr.), og af Gregor af Nyssa (ca. 335-394) i dennes værk Moses' liv. ${ }^{8}$

For at se nærmere på metaforen 'mørke' og de potentialer, den indeholder, vil den spanske teolog og karmelit Johannes af Korsets (1542-1591) reception og videreudvikling af denne kunne anvendes med stort udbytte. Johannes' negative teologi, herunder hans metafor 'den mørke nat', står som selve kulminationen af middelalderens reception af oldkirkens apofatiske teologi. ${ }^{9}$ Hvad Johannes imidlertid forstår med 'den mørke nat', og hvilken betydning den har for sjælens vej imod foreningen med Gud, bliver tydeligt i hans digt 'I en mørk nat' (En una noche oscura) og dettes to kommentarer 'Bestigningen af bjerget Karmel' (Subida del monte Carmelo) og 'Sjælens mørke nat' (La noche oscura del alma). For at belyse Johannes' negative teologi vil en refleksion over disse teksters indhold være nødvendig. Dette ses i det følgende, med fokus på særligt tre ting.

For det forste vil det fremgå, hvorledes Johannes formår at omsætte den negative teologis teoretiske og sproglige metode til et praktisk spirituelt program, en sjælelig proces, i hvilken den negative teologis benægtende tale om Gud i sproget bliver til sjælens aktive fornægtelse af alt, der er finit og skabt for derigennem at nærme sig den infinitte Gud igennem askese og tro. For det andet vil Johannes' beskrivelse af sjælens passive lidelse i kommentaren 'Sjælens mørke nat' blive belyst, da han helt tydeligt etablerer en forbindelse mellem sjælen og den gudsforladthed og annihilation, Kristus oplevede under sin korsfæstelse. Den sjælelige lidelse i 'den mørke nat' finder således sit fuldkomne udtryk i Kristi passionsberetning. For det tredje vil Johannes' negative teologi, herunder digtet 'I den mørke nat', blive bragt ind i en nutidig og postmoderne teologisk diskurs. Formålet med dette er at undersøge, om det er muligt at foretage en ny teologisk læsning og forståelse af den. For at gøre denne diskussion vedkommende vil bidragene til den være en kombination af både en teologisk (jf. Rowan Williams, den nuværende ærkebiskop af Canterbury og Graham Ward, medstifter af den teologiske bevægelse Radical Orthodoxy) og en filosofisk observans (jf. Jacques Derrida, fransk filosof og dekonstruktionens fader). Den nye læsning vil blive betegnet credo ut amem - Jeg tror for at elske.

8. Gregor of Nyssa, The life of Moses (New York: Paulist Press 1978), 94-97.

9. Andrew Louth, The origins of the Christian mystical tradition, from Plato to Denys (Oxford: Oxford University Press 2007), 176. 


\section{Johannes' spirituelle program}

Det interessante ved Johannes' værker er ikke kun hans sproglige brug af den negative teologis teoretiske metode og dens metaforer, men også den måde, hvorpå han overfører denne metodik til også at gælde sjælens spirituelle progression mod Gud. For Johannes bliver den negative teologis teoretiske metode således omsat til en sjælelig vej, som sjælen må begive sig ud på for at blive forenet med Gud (unio mystica). Det er ved denne praktiske anvendelse af den negative teologis metode, at Johannes bliver en central figur inden for forståelsen og anvendelsen af den apofatiske teologi i kristen fromhedspraksis. ${ }^{10}$

Johannes betegner helt overordnet den proces, som sjælen gennemlever, fra begyndelse til ende, med metaforen 'den mørke nat'. 'Den mørke nat' skal betragtes som én 'nat', der falder i tre dele. ${ }^{11}$ Den første del af denne 'nat' indebærer, at sjælens sansende del skal tage afstand og se bort fra alle skabte genstande. Den anden del af den sætter Johannes i forbindelse med troen. Denne del er fuldstændigt mørk for sjælens åndelige del. 'Den mørke nats' tredje del repræsenterer Gud selv og skal betragtes som bringende dagens lys til sjælen, der befinder sig i et mørke af lidelse, tomhed og gudsforladthed. De tre dele kan billedligt bedst forstås ved at blive set som tusmørke, midnat og daggry. ${ }^{12}$ Sjælen må gennemleve hele 'den mørke nat', inden den kan betragtes som helt forenet med Gud i kærlighed. 'Den mørke nat' er således et dynamisk billede på de forskellige sjælelige tilstande, som sjælen kontinuerligt bevæger sig ind og ud af. Denne dynamik bliver også tydelig ved, at Johannes definerer 'den mørke nats' dele som værende af enten aktiv eller passiv karakter afhængigt af, om det er sjælen selv eller Gud, der er den agerende part.

\subsection{Sjalens aktivitet i 'den mørke nat'}

Inden en nærmere belysning af Johannes' spirituelle program er det nødvendigt at være klar over, hvem han henvender sig til, og hvad hans primære anliggende er. Johannes henvender sig nemlig langtfra til alle, men specifikt til sin egen ordens nonner og munke. ${ }^{13}$ Hans primære anliggende er at drøfte de vanskeligheder, som disse ordens-

10. Rowan Williams, "The deflections of desire", Silence and the Word, red. Oliver Davies \& Denys Turner (Cambridge: Cambridge University Press 2008), 117.

11. Subida I.2.5.

12. K. Kavanaugh, O. Rodriguez, The collected Works of St. John of the Cross (Washington: ICS Publications 1991), 121.

13. Subida Prologo.9. 
folk møder, når Gud begynder at bringe dem ind i 'den mørke nat'. Det sker nemlig ofte, at disse mennesker ikke ønsker at gå ind i 'den mørke nat', da de mangler den fornødne forstålse for, hvad der sker i den. Deres manglende forståelse forklarer Johannes med, at de ikke har egnede vejledere. De kommer derfor aldrig helt tæt på Gud, men forbliver på et lavt stade i deres gudsforhold, selvom de kunne havde nået en langt højere gudserkendelse.

Johannes behandler i sin kommentar 'Bestigningen af bjerget Karmel' sjælens aktive arbejde i den første del af 'den mørke nat'. Sjælen må i denne del nærme sig Gud igennem aktiv sjælelig fornægtelse, forstået som asketiske øvelser, efterfølgelse af Kristi liv, meditation og praktisering af de tre kristne teologiske dyder: tro, håb og kærlighed. ${ }^{14}$ Askesen har sin absolutte nødvendighed, da den ifølge Johannes skal være med til at tømme og fratage sjælens sansende del, bestående af de fem ydre sanser (synet, hørelsen, smagen, lugtesansen og følesansen), samt de tre indre sanser (forestillingsevnen, fantasi og sansehukommelsen) dens begær efter alt, der er skabt. Sjælens sanselige begær bliver ved asketiske øvelser gradvist bragt til ro og stilnet. Således kan sjælen synge, at dens hus er blevet stille, hvilket den gør i det første vers af digtet 'I en mørk nat'. Huset skal forstås som en metafor for sjælens sansende del. ${ }^{15}$

\section{I en mørk nat, antændt af kærlighed og længsel \\ - oh lykkelige skæbne - \\ forlod jeg uset mit hus, \\ der nu var blevet stille. ${ }^{16}$}

Udover at udøve askese understreger Johannes også, at sjælen i alt, hvad den foretager sig, må efterligne og imitere Kristus (imitatio Christi). ${ }^{17}$ Det betyder, at sjælen altid skal betragte Kristi liv og gerning som den absolutte norm for efterfølgelse. Den skal, som Johannes beskriver det i det ovenstående vers, være antændt med kærlighed

14. De tre teologiske dyder, (latin: virtutes) tro, håb og kærlighed spiller en afgørende rolle for forstålsen af Johannes' spirituelle program. De har deres oprindelse i Gud selv og kan ikke erhverves ved egen kraft. Det betyder, at det er Gud, der suverænt skænker dem til den sjæl, han ønsker. Deres oprindelse skal findes i en læsning af 1 Kor 13,13. De blev første gang betegnet som teologiske dyder af teologen William af Auxerre (1150-1231) i hans værk Summa super quattuor libros sententiarum. Michael Buchberger und Walter Kasper, Lexikon für Theologie und Kirche, 10. Band (Freiburg: Herder 2001) 297-300.

15. La noche I.13.15.

16. Subida. Conspecto. Canciones vers 1.

17. Subida I.13.2. 
og længsel efter Kristus. Der er således intet andet, hverken nyt eller gammelt, der kan træde i Kristi sted, da Gud allerede har åbenbaret alt i ham. ${ }^{18}$ Sjælen kan derfor kun ved at blive som Kristus i sit indre og i sine ydre gerninger opnå ligedannelse med Gud (conformitas Christi). Det er tydeligt, at kristologien har en helt central plads i Johannes' teologi, der ikke kan forstås ret uden denne vægtning. Johannes' mystik bliver derfor kun igennem kristologien teocentrisk. ${ }^{19}$ Det betyder, at Johannes' negative teologi ikke tager udgangspunkt i mystiske oplevelser, men i den billedløse tro på Guds inkarnerede ord, Kristus. Troen står for Johannes i direkte modsætning til mystiske oplevelser, da dens indhold ikke lader sig formidle i en mystisk oplevelse. Johannes beskriver ligefrem troen som 'en mørk nat' for forstanden. Det er derfor, han gentagne gange i både 'Bestigningen af bjerget Karmel' og 'Sjælens mørke nat' advarer mod, at sjælene udelukkende bygger deres gudsforhold på oplevelser, visioner og tegn. Mystiske oplevelser er absolut en del af sjælens spirituelle progression imod Gud, men de er altid sekundære i forhold til troen. ${ }^{20}$

\subsection{Den infinitte Gud og skabervarket}

Den distinktion, som Johannes foretager imellem de mystiske oplevelser, som sjælen modtager igennem fx diskursiv meditation, og troen på den treenige Gud, er helt central for forståelsen af hans teologi. Den bygger nemlig, ligesom resten af Johannes' spirituelle program, på den negative teologis radikale skelnen imellem det finitte skabte og den infinitte Gud. Selvom dette er et faktum, betyder det dog langt fra, at Johannes ikke kan tildele skaberværket nogen positiv betydning. Johannes lovpriser skaberværket flere steder i sit forfatterskab, særligt i værket 'Åndelig sang' (Cántico espiritual) (San Juan de la Cruz 1993, 581-776). Det er dog vigtigt at fremhæve, at han lovpriser skaberværket som netop "værende skabt". Skaberværket opnår kun sin værdi ved at vise tilbage til dets skaber. Det er i denne relation, at sjælen ofte kommer til at misforstå Guds intention med hans skaberværk. Johannes understreger, at sjælen ofte kommer til at elske og begære skaberværket, herunder også mystiske oplevelser og åbenbaringer, på bekostning af skaberen. Sjælen bliver dermed i Johannes' terminologi til et ufrit slavehjerte, der ikke kan forenes med Gud,

18. Subida II.22.5.

19. Hans Urs von Balthasar, The Glory of the Lord (San Francisco: T. \& T. Clark Limited 1986), 163.

20. Turner betragter ligefrem Johannes' negative teologi, som en direkte kritik af hans samtids oplevelsesrelaterede mystik, herunder også Teresa af Avilas (15151582) teologi. Turner (1995), 250-251. 
fordi det har bundet sin kærlighed til det skabte. ${ }^{21}$ Sjælen har i sin kærlighed til det skabte forsøgt at ligestille noget finit med den infinitte Gud, som intet kan ligestilles med. Den infinitte Gud er således fuldstændig suveræn i forhold til sit finitte skaberværk, som han har skabt ex nibilo. På trods af den ontologiske forskel, der eksisterer imellem det skabte og den transcendente Gud, forsøger Johannes alligevel at etablere en form for kommensurabilitet mellem Gud og den skabte sjæl, idet han hævder, at sjælen, selvom den er skabt, har potentiale til at participere i det guddommelige. ${ }^{22}$ Den har denne mulighed, fordi den er skabt i Guds billede, imago Dei. Johannes befinder sig derfor klart i forlængelse af Thomas Aquinas (1225-1274), herunder den rhinlandske dominikanske tradition fra Albert den Store (1206-1280), ved at fastholde, at sjælen i sig har en refleksion eller et spejlbillede af den infinitte Gud. ${ }^{23}$ Dette betyder, at sjælens grundlæggende tilstand, som imago Dei, ikke er forsvundet ved syndefaldet, men at denne stadig væk determinerer sjælens grundlæggende ontologiske status i dens forhold til Gud. Det, som syndefaldet har bevirket, er, at sjælen ikke længere er forbundet med ham i det, Johannes betegner som lighedens forening (unión de semejanza). ${ }^{24}$ Johannes mener hermed, at sjælens vilje ikke længere er i overensstemmelse med Guds, men ligefrem kan være i direkte modsætning til den. Syndefaldet har således haft en betydelig negativ effekt på sjælens forhold til Gud. Det ses tydeligst ved sjælens begær efter og kærlighed til det finitte skaberværk. Sjælen krænker derved gang på gang Gud ved at elske det skabte. Grunden til dette er, at kærlighed ifølge Johannes ikke blot skaber lighed imellem den, der elsker og det, der elskes, men underordner den, der elsker, under det, der elskes. ${ }^{25}$ Ved at elske det skabte tilsnavser sjælen således sin egen gudbilledlighed. ${ }^{26}$ Det er derfor, Johannes igennem hele sit værk 'Bestigningen af bjerget Karmel' fremhæver, at sjælen må tage afstand fra og fornægte alt naturligt skabt for aktivt at vende sig tilbage imod sin prælapsariske kærlighedsrelation, Gud. ${ }^{27}$

21. Subida I.4.6.

22. La noche II.21.5.

23. S. Thomae Aquinatis, Opera Omnia vol. 2 -Summa Contra Gentiles- Summa Theologiae (Stuttgart: Friedrich Frommann Verlag 1980), ST I.q.93.

24. Subida II.5.3.

25. Subida I.4.3.

26. Subida I.9.1.

27. Subida I.5.2. 


\subsection{Troen - sjalens lys $i$ mørket}

Det er imidlertid ikke kun den postlapsariske vilje i sjælens andelige del, der ikke er i overensstemmelse med Guds længere. Forstanden og erindringen er det i høj grad heller ikke. Det betyder, at forstanden ikke længere kan forstå Guds væsen, men erfarer ham som 'en mørk nat'. ${ }^{28}$ Der er i Johannes' refleksion over Guds væsen således en tydelig parallel til den tidligere omtalte dionysiske forståelse af Gud. Johannes understreger, at den eneste måde, hvorpå de tre åndelige evner igen kan komme til at virke efter deres guddommelige hensigt, er, at de bliver renset og omdannet ved de tre teologiske dyder: troen, håbet og kærligheden. ${ }^{29} \mathrm{Da}$ troen i Johannes' spirituelle program har afgørende betydning for sjælens spirituelle progression mod Gud, vil der i det følgende blive stillet skarpt på den.

Troen er på den ene side det middel (medio), der skal til, for at foreningen med Gud kan blive realiseret, og på den anden side den teologiske dyd, der disponerer sjælen for at kunne modtage kontemplation. ${ }^{30} \mathrm{Ud}$ over at troen har disse virkninger på sjælen, oplyser den også sjælen, selvom denne er uforståelig og ufattelig for forstanden. ${ }^{31}$ Dette virker umiddelbart som en selvmodsigelse, da det tidligere er blevet understreget, at troen for Johannes er ligesom 'en mørk nat' for forstanden. Det er dog langt fra tilfældet. Årsagen til denne sproglige tvetydighed skal findes i Johannes' tidligere belyste distinktion mellem det skabte og det uskabte. Troen har som teologisk dyd sin oprindelse i den transcendente Gud. Den vidner dermed om noget, der for den menneskelige erkendelse er utilgængeligt og fremmed. Troen giver ikke en kundskab og en viden forstået som forstandsmæssig erkendelse, der er opnået igennem sjælens sansende del, men den blænder derimod forstanden. ${ }^{32}$ Troen har denne virkning på forstanden, fordi den efter syndefaldet har mistet muligheden for at erkende Gud fuldt ud. Sjælen opfatter derfor troen som et 'uigennemtrængeligt mørke', selvom den i virkeligheden har sin oprindelse i sel-

28. Subida II.1.1.

29. Sjælens traditionelle opdeling i tre højere sjælsevner finder sin oprindelse i Augustins definition af sjælen i hans værk De Trinitate. Augustin (354-430) lægger i dette værk vægt på, at de tre evner ikke skal forstås som tre fra hinanden adskilte evner, men derimod som én substans (una substantia). Johannes overtager Augustins opdeling af sjælens sammenhængende evner (Subida III.1.1). Han understreger, i relation til forstålsen af sjælens enhed, at sjælen ikke kan forenes med Gud, hvis de tre evner ikke arbejder synergetisk sammen. Aurelii Augustini, Corpus Christianorum Seria Latina L, Aurellii Augustini Opera Pars XVI, 1 De Trinitate Libri I-XI (Turnhout: Brepols Editores Pontificii 1968), Liber X.XVIII.

30. Subida II.8.1.

31. Subida II.3.4.

32. Subida II.3.4. 
ve lyset, Gud, og dermed selv er en stråle af lys. ${ }^{33}$ Det er derfor, at jo mere troen får lov til at formørke og lede forstanden, desto mere oplyst kan sjælen blive i forhold til Guds virkelighed. ${ }^{34}$ Troen fungerer således som sjælens vejleder og lys. Derfor kan sjælen synge, ligesom den gør det i det andet vers af digtet I en mørk nat', at den i troen har fundet mørke, - mørke forstået således, at den ikke længere støtter sig til sine egne evner, men alene til troen. ${ }^{35}$

2. I mørke og i stilhed,

forklædt, ad den hemmelige stige

- oh lykkelige skæbne -

i mørke og i smug

forlod jeg mit hus, der nu var blevet stille. ${ }^{36}$

\section{Sjælens mørke nat}

Den anden del af 'den mørke nat' begynder, når Gud, mens sjælen mest fryder sig over sine egne bedrifter i spirituelle øvelser, med ét formørker sjælens sanser. ${ }^{37}$ Denne guddommelige handling er meget smertelig for sjælen. Johannes understreger nødvendigheden af den, da sjælen, selvom den har praktiseret askese og meditation i håbet om at frigøre sig for alt skabt, stadig ikke er blevet tilstrækkelig nøgen og tom for verdens finitte objekter. Tværtimod er dens begær efter det skabte blevet udskiftet med et langt mere sofistikeret begær, der nu retter sig imod selve den asketiske praksis. Sjælen er fx begyndt at begære og nyde mortifikation og bodshandlinger ${ }^{38}$ og at bede med en rosenkrans ${ }^{39}$. Den ontologisk set højere sjæl er således stadigvæk underordnet det skabte. Gud må derfor på en langt mere aktiv facon end tidligere begynde at rense sjælen for dens ufuldkommenheder, for dens begær efter alt, hvad der er finit. Denne renselse og illumination begynder, når Gud skænker sjælen kontemplation.

For Johannes er kontemplation den nådegave, hvormed Gud antænder sjælen med sin kærligheds ånd. Det er med andre ord Gud, der i hemmelighed indgyder sig selv i sjælen. ${ }^{40}$ For sjælens sansende

33. Subida I.2.5.

34. Subida II.3.4.

35. Subida II.1.1-2.

36. Subida. Conspecto. Canciones vers 2.

37. La noche I.8.3.

38. La noche I.1.3.

39. La noche I.3.1.

40. La noche I.10.6. 
del bevirker kontemplationen, at sanserne bliver rettet ind efter og underordnet dens åndelige del. ${ }^{41}$ Formålet hermed er, at sjælen bliver fuldstændig afhængig af de tre teologiske dyder, som har formørket sjælens tre evner, forstand, erindring og vilje. Under Guds kontemplative selvindgydelse må sjælen forholde sig passivt, dvs. forblive i stilhed og i kærlig opmærksomhed rettet mod Gud alene. ${ }^{42}$ Sjælen må med Johannes' egne ord bevæge sig væk fra sin barnlige tankegang og den omtale af Gud, i hvilken den forsøgte at gøre Gud sanselig og meditativ erkendbar og lade den mørke og billedløse tro være dens eneste vejviser til den infinitte og ubeskrivelige Gud. ${ }^{43}$

Den mest lidelsesfulde periode i den anden del af 'den mørke nat' begynder, når Gud indgyder sin visdom i sjælens åndelige del. Sjælen erfarer nu med stor voldsomhed sin syndighed og ufuldkommenhed i forhold til Gud. Johannes beskriver nogle af de oplevelser, som Guds kontemplative visdom medfører i sjælen, på følgende måde: "For virkeligt, når den rensende kontemplation er voldsomst, oplever sjælen dødens skygge, dødens klager og helvedets lidelser meget levende, ligesom det at føle sig uden Gud er...”. 44

Det umiddelbart mest smertefulde er, at sjælen oplever Gud som fraværende i sin lidelse. Der er dermed klare linjer til Kristi korsord i Markusevangeliet kap. 15,34: "Min Gud, min Gud hvorfor har du forladt mig?" Denne sammenhæng er dog langt fra en tilfældighed. Det blev allerede tidligere konstateret i denne artikel, at sjælen i sin spirituelle progression mod Gud skulle efterligne Kristus. ${ }^{45}$ Det betyder at lade sig sanseligt og åndeligt korsfæste. Sjælen er dermed i sin følelse af gudsforladthed og åndelige tilintetgørelse kommet endnu tættere på Gud, selvom den oplever, at det modsatte er tilfældet. Ved at inddrage det paradoks, at Gud er tættere på sjælen, når denne føler sig gudsforladt, har Johannes genoptaget et tema, der i den apofatiske tradition kan ledes tilbage til Angela af Foligno (1248-1309). 46

Sjælen undergår således sin egen sanselige og åndelige død i denne del af 'den mørke nat' og må alene ved tro håbe på, at Gud i nåde oprejser den i kærlighed. Det sjælelige udfald af Guds kontemplative

41. La noche I.8.1.

42. La noche I.10.4.

43. La noche II.3.3.

44. La noche II.6.2.

45. Subida II.7.1-13.

46. Den italienske mystiker Angela af Foligno beretter i sine erindringer om en lignende gudsforladthed: "And when my soul begins to see all its virtues falling and withdrawing, I am overcome with fear and grief; and I cry out to God shouting to Him over and over again almost continuously: My son, my son, do not abandon me, my son". Cristina Mazzoni, Angela of Foligno's Memorial (Cambridge: Boydell \& Brewer 1999), 65. 
indgydelse er, at sjælen både i sine sanser og sin ånd er fuldstændigt tilintetgjort (aniquilado) og renset for sit begær efter alt skabt. Idet sjælen er blevet tom og intet længere forstår og begærer, understreger Johannes, er den derved blevet modtagelig for alt i Gud. ${ }^{47}$ Sjælen kan med andre ord i åndelig frihed ved tro, håb og kærlighed nu kommunikere med den ubegribelige og guddommelige visdom. ${ }^{48}$ Johannes beskriver, at sjælen på dette tidspunkt i sin spirituelle progression kan begynde at nyde frugterne af de tårer, den græd i 'den mørke nat'. 49 Sjælen oplever dermed ikke kun Guds indgydte kontemplation som lidelsesfuld og smertelig, men begynder nu at erfare den som det, den $i$ virkeligheden er: en flamme af kærlighed (el fuego de amor) der antænder sjælen med længsel. ${ }^{50}$ Denne flamme antænder nu ikke kun sjælen med længsel. Den giver også sjælen det, Johannes betegner som kærlighedens sår (herida amor). ${ }^{51}$ Det sår får hele sjælen til at brænde med en indre lidenskab og et begær efter at blive forenet med Gud. Sjælen kan ligefrem føle, at hvis den ikke hurtigt bliver forenet med Gud, dør den af kærlighed.52 Sjælen må derfor, brændende af lidenskab, gå ud i det begyndende daggry, som er den tredje del af 'den mørke nat', og dér finde og blive forenet med sin elskede. Således har 'den mørke nat', som det tydeligt besynges i det femte vers af digtet 'I en mørk nat', været den årsag, der ledte sjælen til foreningen med dens elskede, Kristus.

5. O nat, som ledte mig!

O nat mere elskelig end daggryet!

O nat, som forenede

den elskende med den elskede,

som forvandlede den elskede til den elskende! ${ }^{53}$

\section{Credo ut amem - Jeg tror for at elske}

Formålet med dette kapitel, som det indledningsvist blev antydet, er at bringe Johannes' negative teologi ind i en nutidig teologisk og filosofisk diskurs og på baggrund af denne undersøge muligheden for en ny teologisk læsning og forståelse af den. Navnet på den nye læsning

47. La noche II.8.5.

48. La noche II.9.1.

49. La noche II.10.10

50. La noche II.11.1.

51. La noche II.11.6.

52. La noche II.13.8.

53. Subida. Conspecto. Canciones vers 5. 
vil være Credo ut amem - Jeg tror for at elske. Læsningens første ord, credo, skal forstås på baggrund af Hebræerbrevets kap. 11,1: "Tro er fast tillid til det, der håbes på, overbevisning om det, der ikke ses." For Johannes er troen denne overbevisning, det eneste middel til forening med den skjulte Gud, der i troen på Kristus bliver nærværende, 'en mørk nat' for sjælens sanser og ånd. ${ }^{54}$ Det andet ord $u t$ skal forstås ud fra, hvad formålet med troen er, nemlig kærligheden. Det sidste ord amem skal læses ud fra forståelsen af, at sjælen ved troen i sit inderste bliver oplært og omdannet til at elske, som Kristus selv elskede, fordi Gud er kærlighed, og den, der bliver i kærligheden, bliver i Gud, og Gud bliver i ham (1 Joh 4,16). En sammenhængende læsning af Johannes' negative teologi indeholder dermed både troens og kærlighedens perspektiv.

Læsestrategien Credo ut amem vil forsøge at problematisere, at den negative teologi kun kan ende med stilhed og talens umulighed. 55 Det vil tværtimod blive påstået, at den negative teologi, for troens indre blik, altid vil ende i kærlighedens lovprisning af den Gud, der har åbenbaret sig i Jesus Kristus. Den kan nødvendigvis intet andet. ${ }^{56}$ Dette er også præcis det, der sker i Johannes' digt 'I en mørk nat'. Sjælen besynger i digtet sin kærlighed til sin elskede, Kristus, som 'den mørke nat' gjorde det muligt at blive forenet med. Johannes' negative teologi ender dermed ikke i stilhed og den tavse grav, men bliver ligesom Kristi opstandelse fra de døde oprejst og reintroduceret som et nyt sprog, omskabt ved Guds kærlighed og nåde. Det sprog kan aldrig forblive tavst, men må, da kærlighedens natur er at flyde over, lovprise det navn i ord og gerning, som Gud har ophøjet over alle andre navne. Jesus Kristus er Herre, til Gud Faders ære (Fil $2,11)$.

\subsection{Williams og metaforen 'den mørke nat'}

I sin prædiken The Dark Night gennemgår Rowan Williams Johannes' metafor af samme navn og hævder, at 'den mørke nat', sådan som han forstår begrebet, nemlig som en sjælelig tilstand af tomhed

\section{Subida II.8.1.}

55. Jean-Luc Marion pointerer, at den eneste legitime grund til, at talen om Gud kan forstumme og blive til stilhed, er respekten for Gud: "More modestly, the silence suitable to God requires knowing how to remain silent, not out of agnosticism or out of humiliation, but simply out of respect." Jean-Luc Marion, God without being (Chicago: University of Chicago Press 1995), 107.

56. McIntosh er inde på en lignende forståelse af det endelige resultat af den apofatiske tale. McIntosh (1998), 124:"... it [ the apophatic speech] might also take the form of an explosion of speech...”. 
og gudsforladthed, bedst lader sig forklare i lyset af Kristi passion. ${ }^{57}$ Williams etablerer derved i sin forstålse af selve metaforen en tydelig forbindelse til kristologien. Sjælen må for at nærme sig Gud efterfølge Kristus og ligesom ham underlægge sig Hans vilje. Det betyder, at sjælen må opgive de falske billeder (false images of God), som den har af Gud, og lade Gud være Gud (Williams 1995, 83). 'Den mørke nat' bliver sjælens mulighed for at gøre dette. Williams forklarer, at i stedet for at vende sig væk fra mørket skal sjælen lade dette komme over sig. Kun i mørket kan sjælen nemlig nærme sig Gud og slippe fri af sit eget manipulerende og selviske ego (Williams 1995, 84). Sjælen har i dette mørke intet andet at holde sig til end troen på Kristus, da alle religiøse oplevelser og retningslinjer er forsvundet (Williams 1995, 81). Selv om 'den mørke nat' fører sjælen ned i dødsriget, understreger Williams dog, at dette langt fra er sjælens endelige destination. Forude venter sjælens åndelige opstandelse. Den indtræffer, når Gud bryder igennem mørket som et lys og sætter sjælen fri til at blive elsket af Ham. Det vigtige ved dette er, at den kærlighed, som sjælen modtager i kraft af sin opstandelse, formår at vende den udad. Den kan derefter aktivt give sig selv hen i kærlighed til Kristus og til sine brødre og søstre (Williams 1995, 84). Sjælen bliver med andre ord igennem Guds kærlighed sat i stand til at give denne videre til sin næste og tilbage til Gud selv. Der synes således at kunne drages en klar parallel mellem Williams' læsning og Niels Henrik Gregersens nådesteologi. 58

En kort konklusion af den læsning, som Williams foretager, må være, at sjælen ikke skal forsøge at undslippe 'den mørke nat'. Den skal tværtimod lade 'natten' komme over sig og lade troen på Kristus være dens vejviser i mørket. Resultatet af 'den mørke nat' bliver, at sjælen, efter at den er nedfaret til dødsriget, bliver oprejst af Gud og sat fri til at elske Ham og sin næste.

\subsection{Derrida og den negative teologi - et sprog $i$ krise}

Jacques Derrida nærmer sig den negative teologi fra en helt anden vinkel end Williams. I sit essay Saufle nom forsøger Derrida at analysere den negative teologi ud fra dens rolle som sproglig udtryks-

57. Rowan Williams, A Ray of Darkness (Cambridge: Cowley Publications 1995), 82.

58. Niels Henrik Gregersen viser i sin artikel Generøsitetens teologi, at Guds nåde, forstået som en gave, gør modtageren i stand til at give den videre. Nåden flyder med andre ord over, videre og tilbage igen og resulterer $i$, at mennesket svarer Gud med lovprisningens overskud. Niels Henrik Gregersen, "Generøsitetens teologi”, Dansk Teologisk Tidsskrift 71 (2008), 77-99 (98-99). 
form..$^{59}$ Derrida viser, at den negative teologi, som metode, må betegnes som et sprog i krise, da den udtømmer sig selv for mening (kenosis of discourse) ${ }^{60}$ igennem gradvis benægtelse (Derrida 1993, 50). Resultatet af denne sproglige metode bliver, at den til sidst har udtømt sig selv for muligheden for overhovedet at tale om sit primære 'objekt', Gud. Derrida kan dermed konkludere, at den negative teologi i sin udtømning af mulighederne for at tale om Gud kommer til at fungere som en kritik af ontologien, teologien og sproget (Derrida 1993, 50-51). Den negative teologi bliver med andre ord ved sin benægtelse af muligheden for tale om Gud en kritik af Gud selv. ${ }^{61}$ Det er på baggrund af denne konstatering, at den negative teologi ofte er blevet sat i forbindelse med ateismen (Davies \& Turner 2008, 1-3). For Derrida er der således et latent problem ved selve denne teologis måde at ytre sig om Gud på. Den er med Derridas egne ord et sprog, der indeholder lidelse (passion), i og med at det ikke kan komme til rette med sit objekt (Derrida 1993, 59). Lidelsen i den negative teologi består dog også $\mathrm{i}$, at den hele tiden må bevæge sig videre i sit forsøg på at overskride sprogets grænser. Den finder aldrig et fast sted, hvorfra den kan at ytre sig i faste vendinger. Den negative teologi er derfor altid i udvikling hen imod et nyt ukendt sted, der er umuligt at betræde, men som den er nødt til at begive sig ind på. ${ }^{62}$

Konkluderende betyder dette, at den negative teologi i Derridas reception skal forstås som et sprog i krise, der i sin jagt på at negere Gud i alle sproglige udtryk paradoksalt nok også kommer til at nedbryde sin egen mulighed for at tale om ham. Det udtømmer med andre ord sig selv for mening og indhold. Derridas analyse af den negative teologi ender således ikke i muligheden for en sproglig genindsættelse af Gud eller kærlighedsytring, men derimod i sproglig umulighed og selvdestruktion.

\subsection{Ward, kenose og navngivning}

Graham Ward viser i sit essay Kenosis and Naming, at begrebet kenose i en kristen sammenhæng aldrig eksisterer alene, men altid opfølges af

59. Jacques Derrida, On the name (Stanford: Stanford University Press 1993), 35-85.

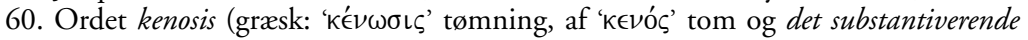
suffiks - $\sigma \iota \varsigma)$.

61. Don Cupitt fremhæver flere steder i sit forfatterskab i lighed med Derrida, at den apofatiske mystiks litterære formål er at kritisere, dekonstruere og nedbryde den klassiske teologi og metafysik. Don Cupitt, Efter Gud. Gudernes komme, gudernes bortgang og religionen efter guderne (København: Forlaget ANIS 2000), 71.

62. Derrida beskriver dette ved at skrive: "Over there, towards the name, towards the beyond the name in the name”. Derrida (1993), 59. 
navngivning. ${ }^{63}$ Der er dermed en afgørende forskel mellem Ward og Derridas forståelse af begrebet kenose. For at vise, at navngivning altid følger sproglig udtømning foretager Ward en eksegetisk læsning af Fil 2,5-11, et locus classicus for kristen kenose-lære. I sin læsning påpeger Ward, at det alene er inkarnationen, der forbinder udtømning med navngivning (Ward 1998, 235). Det er derfor, enhver beskæftigelse med kenose-læren må være en undersøgelse af, hvad det vil sige at være inkarneret (Ward 1998, 236) - med andre ord hvorledes Guds kærlighed lader sig repræsentere og udfylder skaberværket i kraft af Jesu Kristi inkarnation. ${ }^{64}$ Kenose-læren og kristologien er dermed to uadskillelige størrelser. Det er på baggrund af denne sammenhæng, at Ward kan konkludere, at Kristi kenose skal forstås som hans inkarnation og død (Ward 1998, 237), men, som Ward senere understreger i sit essay, skal Kristi død også forstås på baggrund af den kærlighed og lydighed, han havde til sin Fader, Gud (Ward 1998, 241). Der er dermed et klart trinitarisk perspektiv i Wards kenose-forståelse. Han må således siges at være påvirket af Balthasars kenosefortolkning ${ }^{65}$, en fortolkning, der går direkte imod de teologer, der i det nittende århundrede hævdede, at Kristi kenose skulle forstås, som om han afstod fra sine guddommelige egenskaber for at kunne blive menneske (Moltmann 2001, 140). Selvom Ward fastholder, at Kristi kenose resulterer i hans korsfæstelse og død og dermed Ordets passion og stilhed, er dette dog langt fra kenosens endelige udgang. ${ }^{66}$ Tværtimod

63. Graham Ward, "Kenosis and naming: beyond analogy and towards allegoria amoris", Religion, modernity and postmodernity, red. Paul Heelas (Malden: Blackwell Publishers Inc. 1998), 235-257.

64. Gregersen viser, hvorledes Guds kenose i Kristus bliver skaberværkets fylde (græsk: $\pi \lambda \eta ́ \rho \omega \sigma \iota \varsigma$ og dermed Guds selvrealisering i sit skaberværk: "Kenosen betegner således realiseringen af Guds kærlighed, hvad der vel også er meningen i Filipperbrevshymnen”. Niels Henrik Gregersen, "Debatten om Gud anno 20032004", Dansk Teologisk Tidsskrift 68 (2005), 41. Ward arbejder også ligesom Gregersen med begreberne kenose og plerosis. Han viser, at der aldrig kan være tale om kenose, uden at der også tales om plerosis. Der eksisterer således en vekselvirkning og økonomi imellem begge begreber. Det bliver tydeligt i Kristi selvudtømmelse, der leder til hans død, og i Gud Faders efterfølgende kroning af ham. Graham Ward, "Suffering and Incarnation", The Blackwell Companion to Postmodern Theology, ed. Graham Ward (Oxford: Blackwell Publishing Ltd 2005), 202.

65. Jürgen Moltmann, "God's Kenosis in the Creation and Consummation of the World”, The Work of Love, red. John Polkinghorne (Cambridge: William B. Eerdmanns Publishing Company 2001), 139-140.

66. Ward viser på baggrund af sin læsning af von Balthasar, at Kristi død skaber mulighed for en ny form for samtale mellem mennesket og Gud. Dette er troens mulighed. En tro, der i kærlighed kan se betydningen af Guds død. Ward (1998), 243: "This is the death of the sign [Christ] - its silencing, its judgment 
oprejser og ophøjer Gud Fader sin Søn, Jesus Kristus og giver ham navnet over alle andre navne, Jesus Kristus. Han er "Herre, til Gud Faders ære" (Fil 2,9). Dermed er Sønnen kronet med det navn, som Faderen selv har, og den gensidige kærlighed opretholdt (Ward 1998, 238). Den bagvedliggende mening for Gud Faders navngivning af Sønnen er helt tydelig. Jesu Kristi navn skal tros, bekendes og lovprises i det offentlige rum (Ward 1998, 237).

Som en kort konklusion på Wards forståelse af kenose-læren kan det siges, at Kristi kenose er hans inkarnation og død. Men Kristus forbliver ikke i den tavse og stille grav. Han bliver oprejst af Faderens kærlighed og navngivet med navnet over alle navne.

\subsection{Jeg tror for at elske - Credo ut amem}

Jesus sagde: "Jeg er opstandelsen og livet; den, der tror på mig, skal leve, om han end dør." Så tog de stenen væk og Jesus råbte med høj røst: "Lazarus, kom herud!" Og den døde kom ud, med strimler af linned viklet om fødder og hænder og med et klæde viklet rundt om ansigtet. Jesus sagde til dem: "Løs ham og lad ham gå". 67

Der er en klar grund til, at jeg har valgt at begynde læsningen Credo ut amem med billedet af Lazarus' opvækkelse fra de døde, for der findes i Det Nye Testamente ikke nogen anden historie, ud over Jesu Kristi egen passionshistorie, der ligeså tydeligt belyser, hvad det vil sige at have været i 'den mørke nat' og have overvundet den. ${ }^{68}$ 'Den mørke nat' skal, som Williams understreger, ikke forstås som værende af negativ karakter (Williams 1994, 84). Tværtimod indeholder 'den mørke nat' i denne historie en dobbelt positiv mulighed. Den første er muligheden for, at Lazarus kan blive opvækket fra sin død, og den anden er Jesu Kristi egen mulighed for at herliggøre sig selv og sin Fader i himlen (Joh 11,4). Lazarus' gravkammer bliver i vekselvirkningen mellem kenose og plerosis udtømt ved, at Lazarus kommer ud af graven som en konsekvens af, at graven er blevet fyldt med Jesu

- which only faith in the transcendent meaning of love which frames the text can aright".

67. Dette er min egen omformulering af historien om opvækkelsen af Lazarus fra Johannesevangeliets kap. 11,1-44.

68. Raymond E. Brown viser i sin kommentar til Johannesevangeliet, at historien om Lazarus' opvækkelse fungerer som en pædagogisk og teologisk forudgriben af Jesu Kristi opstandelse. Der er derfor klare relationer mellem de to historier. Raymond E. Brown, The Gospel according to John (i-xii) The Anchor Bible (New York: Doubleday \& Company, Inc. 1966), 430. 
Kristi kærlighed og skaberkraft. Jesus Kristus skaber således nyt liv af dødens umulighed og gør derved umulighed til egen mulighed. Det nye liv, der fylder gravens mørke, er dog betinget af, at den døde har tro (Joh 11,25). Kristi kærlighed og Lazarus' tro er altså de primære faktorer, der er nødvendige for, at opvækkelsen kan blive en realitet. Lazarushistorien har dermed flere helt klare lighedspunkter med Johannes' beskrivelse af 'den mørke nat' og dens resultat. At det forholder sig sådan, vil fremgå tydeligt af det følgende.

Det er allerede blevet vist, at for Johannes af Korset er troen på Kristus sjælens eneste lys i 'den mørke nat'. ${ }^{69}$ Troen muliggør, at den elskede, sjælen, kan finde den elskende, Kristus, i nattemørket uden at fare vild. Williams har derfor ret i sin pointering af, at troen har uvurderlig betydning for sjælens retningssans i 'den mørke nat' (Williams 1995, 81). Troen på Kristus fungerer dog, som Balthasar viser, ikke kun som vejviser for sjælen - den disponerer også denne for at kunne modtage kontemplation, forstået som Guds kærlighed og visdom (Balthasar 1986, 159-160). Troen udvirker ikke Guds aktive indgydelse af sin kærlighed i sjælen, men muliggør dens realisering. Derved fastholdes Gud som suveræn majestæt og gavegiver i forhold til sit finitte skaberværk. ${ }^{70}$

Det er vigtigt at forstå, at Guds formål med sin rensende og illuminerende indgydelse ikke er at fastholde den postlapsariske sjæl i oplevelsen af gudsforladthed og lidelse. Derimod er formålet med kontemplationen at rense den passive sjæl, så den bliver tom for alt, der ikke er Gud, så Gud kan fylde alt i den. Sjælen bliver således ved kontemplationen, sådan som Williams pointerede, renset for alle falske forestillinger om Gud, så at den i frihed kan komme til at elske, både Ham fordi Han er Gud og også sin næste (Williams 1995, 94). Guds kærlighed sætter dermed sjælen fri til aktivt at give denne kærlighed videre, ligesom også Lazarushistorien vidner om. ${ }^{71}$ Lazarus bliver løst fra de bånd, der binder ham til dødens mørke, og sat fri til at elske og lovprise Gud. Johannes' negative teologi ender således ikke i talens umulighed, sådan som Derrida understreger, at den negative teologi altid vil gøre (Derrida 1993, 59). Den ender derimod i sjæ-

69. Subida II.3.4.

70. Keith J. Egan, Carmelite Prayer: A Tradition for the 21st Century (New York: Paulist Press 2003), 8.

71. Gregersen viser, i lighed med den måde jeg forstår Johannes’ kærlighedsbegreb på, at Guds nåde skaber plads til menneskets aktivitet. Mennesket kan derefter give nåden videre til sine omgivelser på samme måde som sjælen, for Johannes, kan give kærligheden videre. Nåde føder dermed mere nåde, ligesom kærlighed avler mere kærlighed. Gregersen (2008), 99. 
lens sang og lovprisning af Kristus som herre og elskede. ${ }^{72}$ Derrida har dog ret i én ting i sin analyse af den negative teologi som sprog, nemlig at den negative teologi er et sprog i krise (Derrida 1993, 50). Det, Derrida ikke ser, er imidlertid, at krisen ikke er til døden, men tjener til Guds herlighed (Joh 11,4). Krisen i sproget ophæves ved troens vidnesbyrd om det ord, der har overvundet dødens og gravens stilhed. Den negative teologi kan derfor aldrig ende i absolut stilhed, da Ordet ikke længere er skjult, men er trådt frem som menneske, er død, blevet ophøjet og navngivet (Fil 2,7-9). Fra at være udtømt for liv er sproget med Faderens kroning af Sønnen blevet genrejst og fyldt med kærlighedens mulighed. Den sjæl, der har gennemlevet 'den mørke nat', kan derfor intet andet gøre end at lade sit hjerte flyde over med kærlighedens doksologi og bekende, "Kristus er opstanden, han er sandelig opstanden" - med ordene fra den ortodokse påskeliturgi. For at sjælen kan komme til denne indsigt i Kristi mysterium, må den med en tro, der tror for at elske (Credo ut amem), gå igennem 'den mørke nat'. Denne 'nat' er dermed sjælens eneste mulighed for i tro at vinde Kristus, og derfor kan sjælen intet andet gøre end at synge 'nattens' pris, ligesom den gør i digtet 'I en mørk nat'.

72. I sin analyse af den negative teologis mulighed for at beskrive Gud konstaterer Marion, at, selv om sproget må blive stille i sin beskrivelse af Gud, kan det aldrig forblive tavst. Forskellen mellem de falske guder (idols) og den levende Gud Kristus er, at idoler forbliver tavse, men den levende Gud indbyder til samtale. Den gave, som mennesket modtager ved Kristi agape, reetablerer samtalens mulighed. Mennesket må således svare på denne kærlighed ved at give den videre til sin næste og ved at lovsynge Gud. Marion (1995), 107: "Love is not spoken, in the end, it is made. Only then can discourse be reborn, but as an enjoyment, a jubilation, a praise". 